\title{
Evaluation of degarelix in the management of prostate cancer
}

\author{
This article was published in the following Dove Press journal: \\ Cancer Management and Research \\ 21 January 2010 \\ Number of times this article has been viewed
}

\author{
Hendrik Van Poppel \\ Department of Urology, University \\ Hospitals Leuven, Campus \\ Gasthuisberg, Leuven, Belgium
}

Correspondence: Hendrik Van Poppel Chairman Department of Urology, University Hospitals Leuven,

Campus Gasthuisberg, Herestraat 49, B-3000 Leuven, Belgium

Tel +32 I6 $346687 /+3216346943$

Fax +32 I6 346931

Email hendrik.vanpoppel@uzleuven.be

\begin{abstract}
Medical castration using gonadotropin-releasing hormone $(\mathrm{GnRH})$ receptor agonists currently provides the mainstay of androgen deprivation therapy for prostate cancer. Although effective, these agents only reduce testosterone levels after a delay of 14 to 21 days; they also cause an initial surge in testosterone that can stimulate the cancer and lead to exacerbation of symptoms ("clinical flare") in patients with advanced disease. Phase III trial data for the recently approved GnRH receptor blocker, degarelix, demonstrated that it is as effective and well tolerated as GnRH agonists. However, it has a pharmacological profile more closely matching orchiectomy, with an immediate onset of action and faster testosterone and PSA suppression, without a testosterone surge or microsurges following repeated injections. As a consequence, with this GnRH blocker, there is no risk of clinical flare and no need for concomitant antiandrogen flare protection. Degarelix therefore provides a useful addition to the hormonal armamentarium for prostate cancer and offers a valuable new treatment option for patients with hormone-sensitive advanced disease. Here, we review key preclinical and clinical data for degarelix, and look at patient-focused perspectives in the management of prostate cancer.
\end{abstract}

Keywords: degarelix, GnRH receptor antagonist, GnRH receptor blocker, prostate cancer

\section{Introduction}

The key role of testosterone in the growth of prostate cancer was first demonstrated back in 1941 by Huggins and Hodges, ${ }^{1}$ since then, androgen deprivation therapy (ADT) has provided the mainstay of treatment for patients with hormone-sensitive advanced prostate cancer. Because of its documented links with therapeutic efficacy, testosterone suppression is now an accepted endpoint in prostate cancer clinical trials and has been used as a surrogate endpoint during the approval of several hormonal treatments. ${ }^{2}$ Prostate-specific antigen (PSA) is currently widely-used in prostate cancer screening and this marker can also be helpful in monitoring treatment response, disease recurrence and potentially in providing evidence of disease progression during prostate cancer ADT. ${ }^{3,4}$ Testosterone production is regulated by two key hormones: gonadotropinreleasing hormone $(\mathrm{GnRH})$ and luteinizing hormone $(\mathrm{LH})$. GnRH is secreted from the hypothalamus in a pulsatile manner and binds to high-affinity cell surface receptors in the pituitary gland, activating a chain of events that lead to synthesis and secretion of $\mathrm{LH}$ and follicle-stimulating hormone (FSH). ${ }^{5} \mathrm{LH}$ stimulates testosterone production and secretion by the Leydig cells of the testes. Bilateral orchiectomy was the first ADT approach used in prostate cancer therapy and rapidly reduces circulating testosterone levels. ${ }^{6}$ Although effective, its irreversibility and associated adverse psychological effects are often unacceptable to patients and so, with the advent of

submit your manuscript | www.dovepress.com 
newer pharmacological approaches to ADT, orchiectomy is now used much less frequently.

GnRH receptor agonists were first introduced in the 1980s and are currently the most commonly used ADT in prostate cancer. ${ }^{7}$ These agents act on the hypothalamic-pituitarygonadal (HPG) axis via a negative feedback mechanism. ${ }^{8}$ Binding of a GnRH receptor agonist to the GnRH receptor initially triggers the secretion of $\mathrm{LH}$, which in turn causes a surge in testosterone production lasting 1 to 2 weeks..$^{9,10}$ This may stimulate prostate cancer cells, and in patients with advanced disease, exacerbate clinical symptoms such as skeletal pain, ureteral obstruction and spinal cord compression, which may lead to paralysis and, in rare cases, death. ${ }^{11,12}$ The clinical effects of flare can be limited by concomitant antiandrogen treatment (eg, flutamide or bicalutamide), ${ }^{13}$ which acts to inhibit the stimulatory effect of the testosterone surge by blocking testosterone binding to androgen receptors in prostate cancer cells. However, this strategy is not always effective and antiandrogens are also associated with additional side effects. ${ }^{14,15}$

Chronic administration of $\mathrm{GnRH}$ receptor agonists eventually leads to suppression of LH, which results in a reduction of testosterone release. However, GnRH agonists may also induce "microsurges" of $\mathrm{LH}$ and testosterone after each re-injection. ${ }^{16,17}$ Overall, $22.6 \%$ of patients in the Zinner et al study ${ }^{17}$ had a testosterone surge on at least one repeat injection; this comprised $18.6 \%$ of patients receiving goserelin $10.8 \mathrm{mg}$ and $27.9 \%$ of those receiving goserelin $3.6 \mathrm{mg}$ depots. No symptoms of clinical flare were reported at the time of surge for any of the patients experiencing a testosterone surge in this study. In a separate study looking at the potential for agonistic stimulation during leuprolide treatment, $5.9 \%$ and $2.9 \%$ of patients receiving leuprolide monthly depot had testosterone increases to $\geq 0.5 \mathrm{ng} / \mathrm{mL}$ after the second and third injection, respectively. ${ }^{16}$ In a further study of 73 patients receiving GnRH agonist treatment, overall, $56.2 \%$ of patients had breakthrough increases in testosterone of $\geq 20 \mathrm{ng} / \mathrm{mL}$, with increases $>50 \mathrm{ng} / \mathrm{mL}$ occurring in $24.7 \%$ of patients. ${ }^{18}$ In contrast to the results of Zinner et al, a significant association was shown between testosterone increases and clinical outcome in terms of PSA progression, demonstrating the importance of keeping testosterone levels low during ADT. The effects were most notable the higher the testosterone breakthrough threshold breached. Further analysis of data from this trial showed that patients who maintained their testosterone levels consistently below $32 \mathrm{ng} / \mathrm{mL}$ had significantly longer PSA progressionfree survival compared with those having any breakthrough increases above this threshold (137 months vs 88 months, respectively; $P<0.03) .{ }^{18}$ A more recent report of data from 129 men with previously untreated prostate cancer and bone metastases demonstrated that risk of death significantly correlated $(P<0.05)$ with the 6-month serum testosterone level achieved during goserelin treatment. ${ }^{19}$ The authors concluded that based on their results, lowering testosterone levels as much as possible should be the goal of ADT in patients with metastatic prostate cancer.

Other pharmacological endocrine options for prostate cancer include the use of estrogens, antiandrogen monotherapy, and complete androgen blockade using an antiandrogen plus a GnRH receptor agonist. ${ }^{7}$ However, these approaches are used infrequently in practice due to concerns about efficacy and/or side effects, which can include cardiotoxicity, gynecomastia, breast pain and liver toxicity. ${ }^{7}$ The need exists, then, for additional effective and well-tolerated treatment options for patients with advanced, hormone-sensitive prostate cancer.

\section{Degarelix: a new GnRH receptor blocker}

The testosterone surge and clinical flare associated with $\mathrm{GnRH}$ agonists led to research into new GnRH analogues that blocked the GnRH receptor directly, thus obviating these agonistassociated problems. GnRH receptor antagonists (blockers) are a new class of endocrine therapy that bind directly to the GnRH receptor, rapidly blocking the release of both LH and $\mathrm{FSH}$, and thereby reducing testosterone secretion (Figure 1). ${ }^{20-25}$ In contrast to the agonists, GnRH antagonists do not cause an initial stimulation of LH production, and therefore do not cause testosterone surge or clinical flare. ${ }^{12}$ Abarelix was the first GnRH antagonist to be licensed for prostate cancer treatment; however, this agent was associated with immediate-onset systemic allergic reactions resulting from histamine release, and so is currently marketed only in Germany. ${ }^{26}$

Degarelix is a new GnRH receptor blocker that has recently been approved for the treatment of men with advanced, hormone-sensitive prostate cancer. ${ }^{27}$ It acts by immediate and competitive blockade of $\mathrm{GnRH}$ receptors in the pituitary; like other GnRH antagonists, degarelix does not cause an initial stimulation of LH production via the HPG axis, and therefore does not cause testosterone surge or clinical flare. ${ }^{12}$

\section{Pharmacology and pharmacokinetics of degarelix}

Degarelix (Ac-D-2Nal-D-4Cpa-D-3Pal-Ser-4Aph (L-hydrorootyl)-D-4Aph (carbamoyl)-Leu-Ilys-Pro-D-Ala$\mathrm{NH}_{2}$ ) is a fully synthetic, linear decapeptide amide analogue 


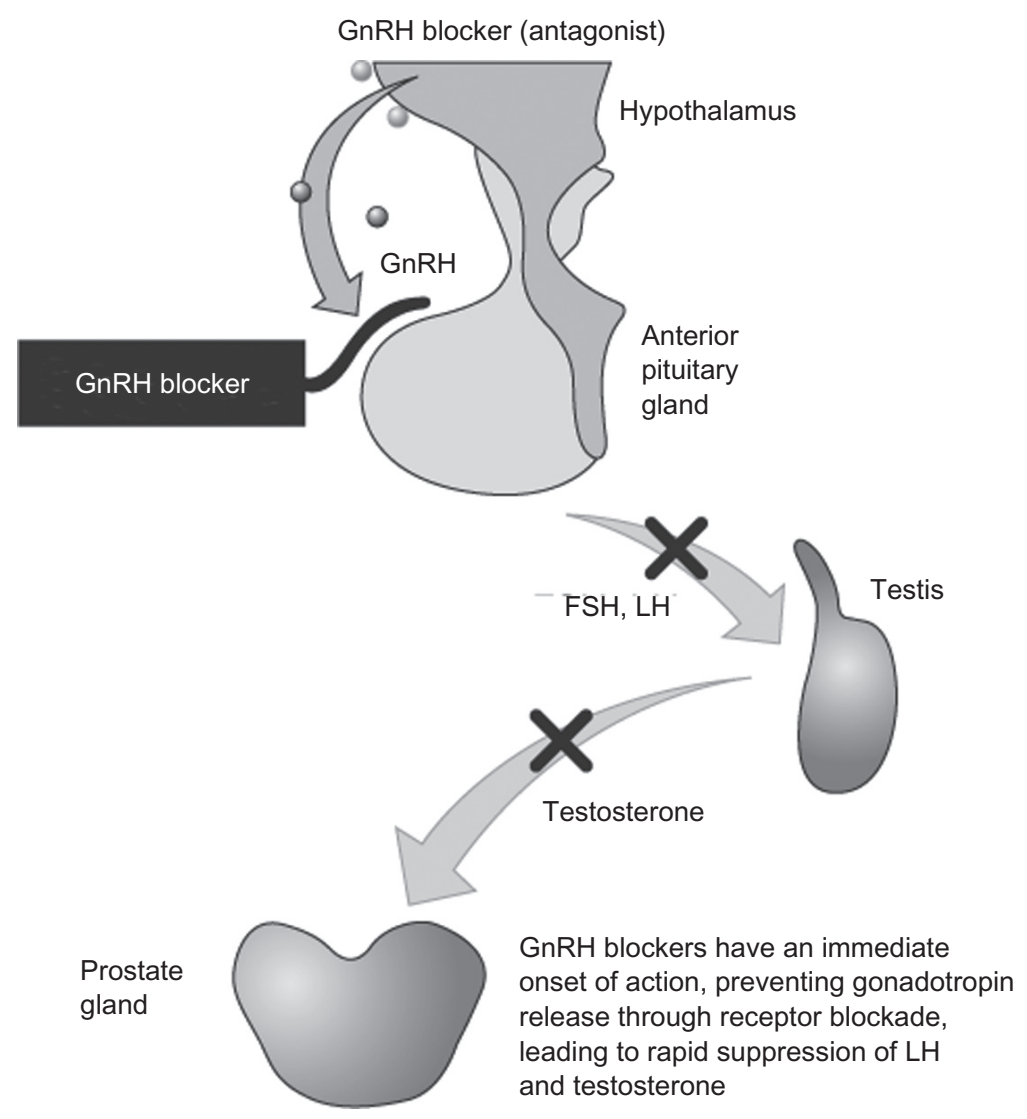

Figure I Mode of action of GnRH receptor antagonists. ${ }^{58}$ Reproduced with permission from Anderson J. Degarelix: a novel gonadotropin-releasing hormone blocker for the treatment of prostate cancer. Future Oncol. 2009;5(4):433-443..$^{58}$ Copyright ( 2009 Future Medicine Ltd.

Abbreviations: $\mathrm{GnRH}$, gonadotrophin-releasing hormone; $\mathrm{FSH}$, follicle-stimulating hormone; $\mathrm{LH}$, luteinizing hormone.

of natural GnRH that contains seven unnatural amino acids, five of which are D-amino acids. ${ }^{28}$

\section{Data from preclinical studies}

The pharmacology of degarelix was initially assessed in various preclinical studies. In vitro radioligand binding assays demonstrated that degarelix has a high affinity to cloned human GnRH receptors expressed on COS-I cells, with a $\mathrm{K}_{\mathrm{i}}$ value of $1.68 \pm 0.12 \mathrm{nM} .{ }^{29}$ Degarelix demonstrated similar functional antagonism to three other $\mathrm{GnRH}$ antagonists (azaline B, cetrorelix and ganirelix) and showed no significant affinity towards other tested receptors. Data from in vitro metabolism studies suggest that degarelix is unlikely to be associated with any clinically significant drug-drug interactions..$^{29}$

The in vivo effect of degarelix on tumor size was investigated in three experimental models of hormone-dependent prostate cancer. Antitumor effects were observed in androgendependent human prostate tumors (PAC120) in nude mice and androgen-dependent rat prostate tumors (Dunning R-3327H) when degarelix was administered at a dose of $2 \mathrm{mg} / \mathrm{kg}$ every
2 weeks or once a month, respectively. At the tested doses, degarelix reduced tumor volume with a similar efficacy to surgical castration..$^{29}$ Degarelix had no effect on the growth of the androgen-independent human prostate tumor PC3.

The pharmacological profile of subcutaneous degarelix was originally assessed in rats and monkeys. ${ }^{25}$ Single subcutaneous injections in rats produced dose-dependent reductions in $\mathrm{LH}$ and testosterone levels and the duration of LH suppression was found to increase with dose. Degarelix fully suppressed LH and testosterone levels for more than 40 days after a single $2 \mathrm{mg} / \mathrm{kg}$ subcutaneous injection in castrated and intact rats (Figure 2) as well as in ovariectomized rhesus monkeys. The testosterone suppression profile during degarelix treatment more closely matched that of orchiectomy compared with the other $\mathrm{GnRH}$ antagonists tested. Furthermore, degarelix showed a longer duration of action than abarelix, ganirelix, cetrorelix, and azaline $\mathrm{B}$ and demonstrated only weak histamine-releasing properties in vitro. A more recent study has confirmed that cetrorelix and abarelix are potent activators of human skin mast cells and that ganirelix is a less potent activator in terms 


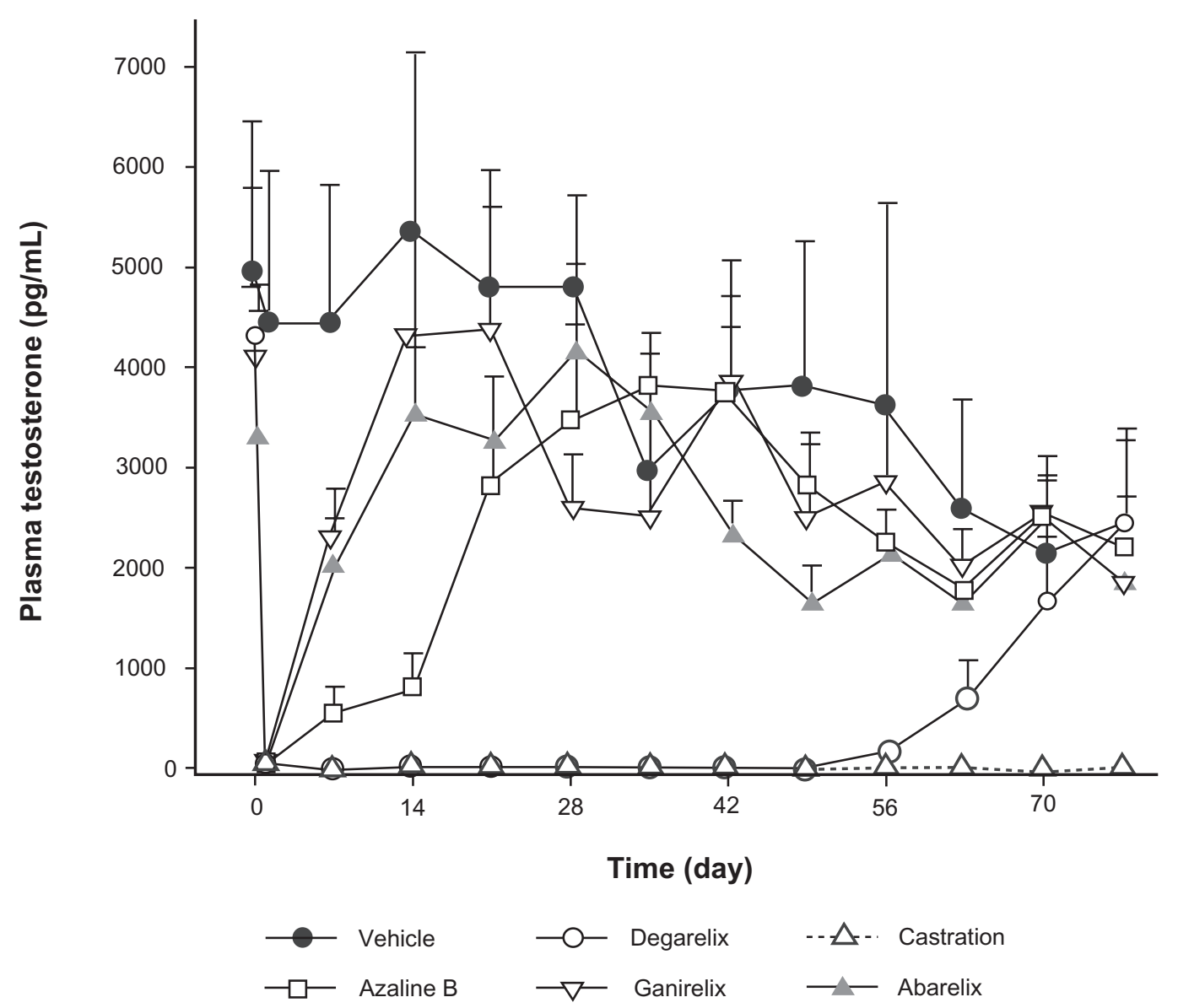

Figure 2 Mean ( $n=8 ; \pm$ SEM) testosterone levels in the intact rat induced by degarelix, abarelix, azaline B, and ganirelix, administered at a dose of $2 \mathrm{mg} / \mathrm{kg}$ in $5 \%$ mannitol, compared with surgical castration. Reproduced with permission from Broqua P, Riviere PJ, Conn PM, Rivier JE, Aubert ML, Junien JL. Pharmacological profile of a new, potent, and long-acting gonadotropin-releasing hormone antagonist: degarelix. J Pharmacol Exp Ther. 2002;301:95-102. ${ }^{25}$ Copyright @ 2002 American Society for Pharmacology \& Experimental Therapeutics.

of inducing histamine release.$^{30}$ In the same study, degarelix had the lowest histamine-releasing potential, suggesting that it is the least likely agent to cause histamine-related immediateonset allergic reactions.

The pharmacological profile of degarelix was also assessed in male beagle dogs. ${ }^{31}$ In this study, administration conditions were varied with respect to route, dose, concentration and volume. The plasma concentration-time profile of subcutaneous or intramuscular degarelix was best described by a two-compartment model, with two input functions to describe the rapid initial increase in the plasma levels, and the prolonged absorption profile of degarelix. Intramuscular administration led to more rapid absorption of degarelix. The relative fraction absorbed varied with the concentration of the dosing solution; the absorbed fraction was reduced by $\sim 50 \%$ when the concentration was increased from 1.25 to $40 \mathrm{mg} / \mathrm{mL}$. The initial rate of absorption was also dependent on concentration, with slower absorption at higher concentrations. After subcutaneous administration, degarelix immediately forms a gel "depot" at the injection site, leading to sustained release of the drug into the circulation. Release from the depot was found to be dependent on the degarelix dose and the administration volume. ${ }^{32}$

\section{Reconstitution and administration of degarelix}

Reconstitution of the lyophilized degarelix powder involves addition of sterile water to the product vial followed by swirling to minimize production of foam. Recently, a study was performed to assess the time taken for reconstitution of two degarelix doses. It was found that average reconstitution times were 2.96 and 4.25 minutes for 80 and $120 \mathrm{mg}$ degarelix doses, respectively (Ferring Pharmaceuticals, data on file). Virtually all (99\%) of the $80 \mathrm{mg}$ vials were reconstituted within 5 minutes compared with $72 \%$ of vials for the $120 \mathrm{mg}$ dose (99\% of which were reconstituted within 8 minutes) (Figure 3). The average concentration of degarelix in the reconstituted samples was $19.9 \mathrm{mg} / \mathrm{mL}$ for the $80 \mathrm{mg}$ dose 
A

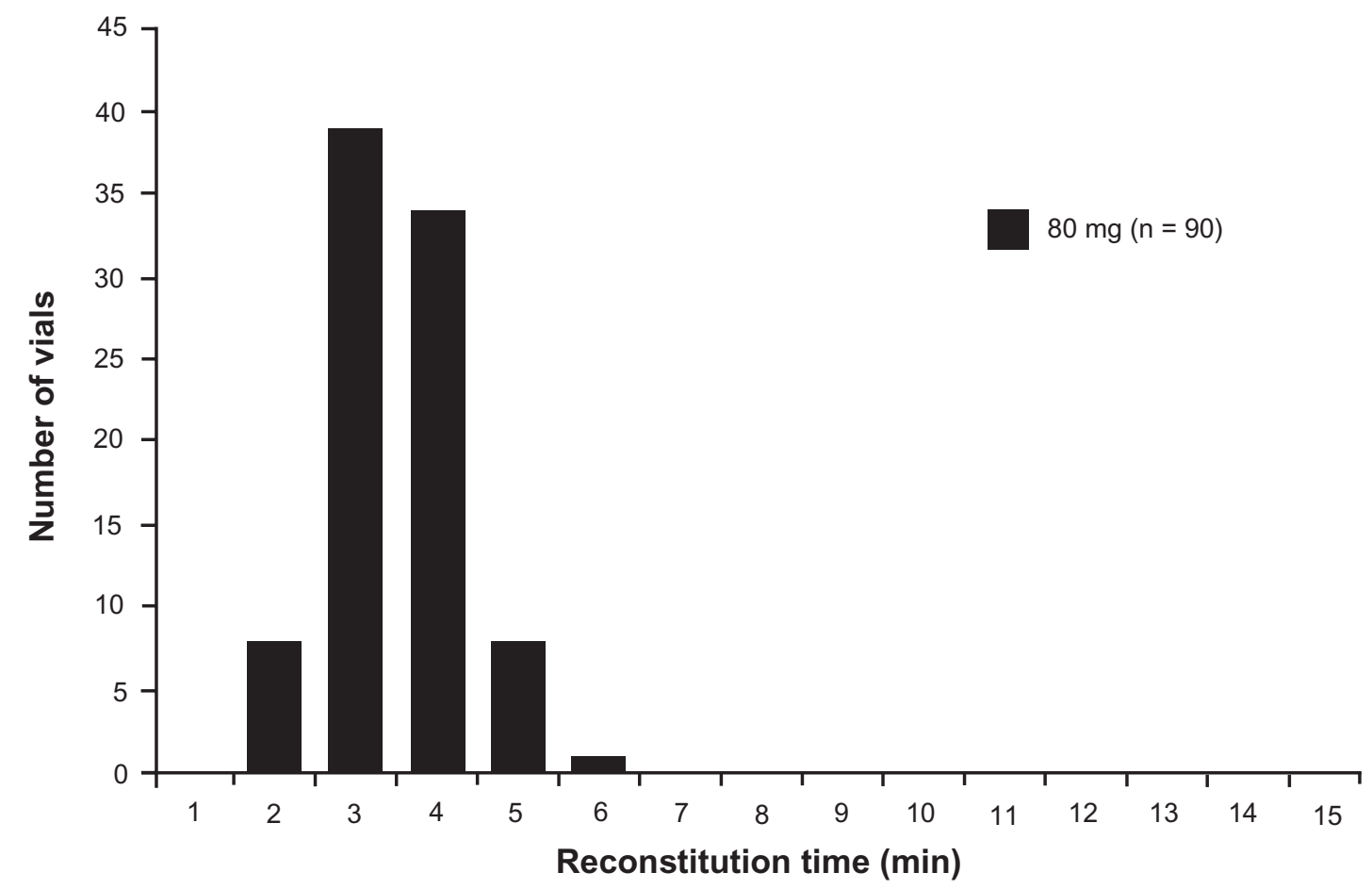

B

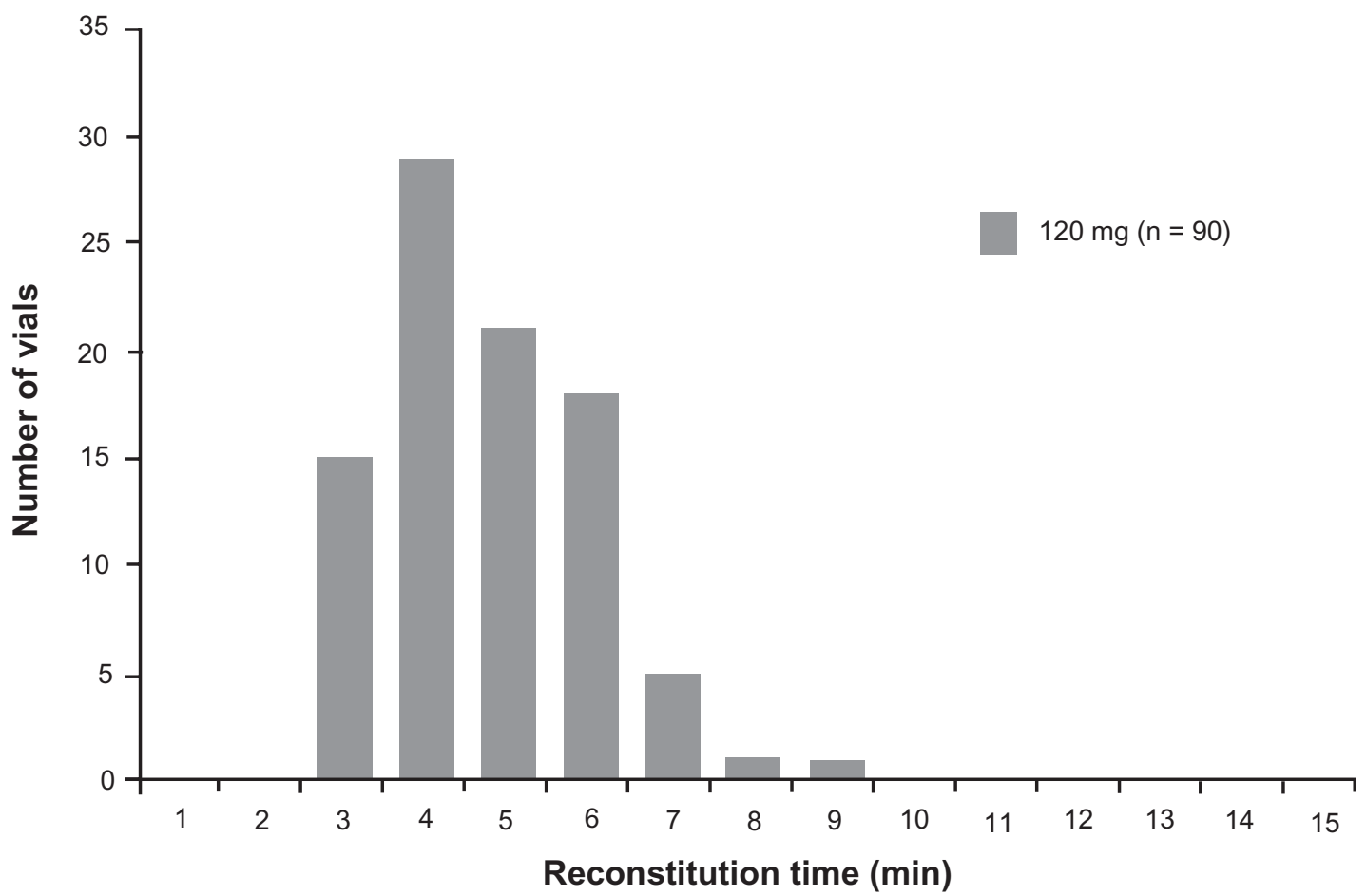

Figure 3 Reconstitution time distribution profiles for degarelix doses of $80 \mathrm{mg}$ (Panel A) and $120 \mathrm{mg}$ (Panel B) (three batches combined). 
and $39.3 \mathrm{mg} / \mathrm{mL}$ for the $120 \mathrm{mg}$ dose, confirming that the reconstitution process in all vials was adequate.

Degarelix is administered via subcutaneous injection into the abdominal subcutaneous fat surrounding the umbilicus. ${ }^{33}$ The $240 \mathrm{mg}$ starting dose is given as two $3 \mathrm{~mL}$ injections (final degarelix concentration of $40 \mathrm{mg} / \mathrm{mL}$ ) and the $80 \mathrm{mg}$ maintenance dose is given as a single $4 \mathrm{~mL}$ injection (final degarelix concentration of $20 \mathrm{mg} / \mathrm{mL}$ ).

\section{Data from clinical studies}

The pharmacokinetics of degarelix were initially assessed in a phase I study in 36 healthy male volunteers. ${ }^{34}$ In this study, single doses of degarelix $(1.5,6.0,15$ or $30 \mu \mathrm{g} / \mathrm{kg})$ were administered via 45-minute intravenous infusions, or a single dose of $20 \mathrm{mg}$ was given intramuscularly or subcutaneously. As was seen in the early preclinical studies, degarelix naturally formed a depot at high concentrations $(\mathrm{mg} / \mathrm{mL})$ after both subcutaneous and intramuscular injection, which resulted in a longer half-life compared with intravenous injection. The pharmacokinetics of degarelix after subcutaneous injection were also found to be dose- and concentration-dependent, and bioavailability was estimated at $30 \%$ to $40 \%$ following both subcutaneous and intramuscular administration. Similar levels of LH, FSH and testosterone suppression were seen when degarelix was administered via the intravenous, subcutaneous or intramuscular routes.

Two further studies in prostate cancer patients assessed the effects of a single dose of degarelix, 120 to $320 \mathrm{mg}$ given in various concentrations in the range of 12 to $27 \mathrm{mg} / \mathrm{mL}$ or subcutaneous degarelix administered in single initiation doses of 200 or $240 \mathrm{mg}$ with maintenance doses of 80, 120 or $160 \mathrm{mg}$. In a combined analysis of these studies, the effects of degarelix were again shown to be dose- and concentration-dependent; higher doses resulted in superior testosterone suppression, but lower concentrations of a given dose yielded better responses. ${ }^{35}$

In early single- and multiple-dose degarelix studies, ${ }^{29}$ the mean terminal half-life was between 23 and 61 days with marked variability between patients and studies. $\mathrm{C}_{\max }$ and AUC were influenced by dose, number of injections and concentration and $T_{\max }$ ranged between 34 and 62 hours. Steady-state plasma levels occurred after 5 to 6 months with the degarelix 240/80 mg regimen. Additional pharmacokinetic data relating to the subcutaneous administration of degarelix $240 \mathrm{mg}$ at a concentration of $40 \mathrm{mg} / \mathrm{mL}$ were gained from the pivotal phase III trial (CS21). ${ }^{29}$ In this trial, the $\mathrm{AUC}_{0-28 \text { days }}$ was 635 (602 to 668) days $* \mathrm{ng} / \mathrm{mL} . \mathrm{C}_{\max }$ was 66.0 (61.0 to 71.0$) \mathrm{ng} / \mathrm{mL}$ and occurred at a $\mathrm{T}_{\max }$ of
40 (37 to 42) hours. Mean trough values were 11 to $12 \mathrm{ng} / \mathrm{mL}$ after the starting dose and 11 to $16 \mathrm{ng} / \mathrm{mL}$ after maintenance dosing of $80 \mathrm{mg} / \mathrm{month}$ (at a concentration of $20 \mathrm{mg} / \mathrm{mL}$ ). In humans, degarelix is subject to common peptiditic degradation during passage through the hepatobiliary system and is mainly excreted as peptide fragments in the feces, with approximately $20 \%$ excreted unchanged in the urine.

\section{Dose-finding studies of degarelix Study designs and patients}

Two phase II, degarelix dose-finding studies of similar overall design were performed in Europe $(\mathrm{CS} 12)^{36}$ and North America (CS14) ${ }^{37}$ Both were open-label, randomized, parallel-group, 1-year studies including adult male patients with histologically confirmed prostate cancer (all stages), in whom hormonal treatment was indicated. Patients were randomized to treatment with different degarelix dose regimens in these two studies. In CS12, 189 patients were randomized to one of six degarelix treatment groups: starter doses of either 200 or $240 \mathrm{mg}$ followed by monthly maintenance doses of 80,120 , or $160 \mathrm{mg}$, all given via subcutaneous injection. ${ }^{36}$ In CS14, 127 patients were randomized to one of two degarelix treatment groups: starter dose of $200 \mathrm{mg}$ followed by monthly maintenance doses of either 60 or $80 \mathrm{mg}$, once again all given via subcutaneous injection. ${ }^{37}$

\section{Efficacy data}

In the European study, $88 \%$ and $92 \%$ of patients in the 200 and $240 \mathrm{mg}$ starter-dose groups, respectively, achieved testosterone levels $\leq 0.5 \mathrm{ng} / \mathrm{mL}$ by day 3 , and there was no evidence of testosterone surge. ${ }^{36}$ The proportion of patients achieving castrate testosterone levels after 1 month of treatment was significantly higher for patients treated with a degarelix starter dose of $240 \mathrm{mg}$ compared with those receiving a starter dose of $200 \mathrm{mg}(95 \%$ and $86 \% ; P=0.048)$. The proportion of patients with castrate levels from month 1 until the end of the study also increased with increasing maintenance dose (Table 1). In this study, inadequate testosterone suppression resulted in withdrawal of $8.5 \%$ of patients, with $50 \%$ of all withdrawals occurring in the lowest dose group (200/80 mg). Median time to a 50\% reduction in PSA was 14 days for all groups and the median time to a $90 \%$ reduction was 56 days for all groups except those receiving degarelix 200/80 mg, which took an average of 84 days. After 12 months of treatment, the median PSA reduction from baseline was $97 \%$ to $98 \%$; overall, $7 \%$ of patients experienced PSA progression. ${ }^{36}$

In the North American study, 89\% of patients overall achieved testosterone levels $\leq 0.5 \mathrm{ng} / \mathrm{mL}$ by day 3 and there 
Table I Percentage of patients with serum testosterone levels $\leq 0.5 \mathrm{ng} / \mathrm{mL}$ (responders) during monthly measurements from day 28 through to day 364 in phase II and III degarelix studies ${ }^{36-38,58}$

\begin{tabular}{|c|c|c|c|c|}
\hline & $\mathbf{n}$ & Responders & $\%$ & $95 \% \mathrm{Cl}$ \\
\hline \multicolumn{5}{|c|}{ Phase II European study } \\
\hline Degarelix 200/80 mg & 28 & 17 & 61 & $4 I-78$ \\
\hline Degarelix 200// 20 mg & 25 & 21 & 84 & $64-95$ \\
\hline Degarelix 200/160 mg & 27 & 26 & 96 & $81-100$ \\
\hline Degarelix 240/80 mg & 30 & 27 & 90 & $73-98$ \\
\hline Degarelix 240// $20 \mathrm{mg}$ & 30 & 27 & 90 & $73-98$ \\
\hline Degarelix 240//60 mg & 25 & 23 & 92 & 74-99 \\
\hline \multicolumn{5}{|c|}{ Phase II North American study } \\
\hline Degarelix 200/60 mg & 45 & 42 & 86 & $73-94$ \\
\hline Degarelix 200/80 mg & 42 & 41 & 98 & $87-100$ \\
\hline \multicolumn{5}{|l|}{ Phase III study } \\
\hline Degarelix 240/I60 mg & 202 & 199 & 98.3 & $95-99$ \\
\hline Degarelix 240/80 mg & 207 & 202 & 97.2 & $94-99$ \\
\hline Leuprolide 7.5 mg & 201 & 194 & 96.4 & $93-98$ \\
\hline
\end{tabular}

Reproduced with permission from Anderson J. Degarelix: a novel gonadotropinreleasing hormone blocker for the treatment of prostate cancer. Future Oncol. 2009; 5(4):433-443. ${ }^{58}$ Copyright (C) 2009 Future Medicine Ltd.

Abbreviation: $\mathrm{Cl}$, confidence interval.

was no significant difference between treatment groups and no evidence of testosterone surge. ${ }^{37}$ Somewhat surprisingly, after 1 month of treatment, there was a trend for improved testosterone control in the $60 \mathrm{mg}$ maintenance dose group compared with the $80 \mathrm{mg}$ group, with $93 \%$ and $83 \%$ of patients treated with these doses, respectively, achieving castrate testosterone levels $(P=0.073)$. The proportion of patients with castrate levels at month 1 who also had castrate levels at the 1-year study visit was $93 \%$ and $98 \%$ in the 60 and $80 \mathrm{mg}$ maintenance dose groups, respectively (Table 1). However, when early failures due to an inadequate starter dose were excluded, a maintenance dose of degarelix $80 \mathrm{mg}$ appeared most effective in maintaining castrate testosterone levels to 1 year ( $98 \%$ vs $93 \%$, for $80 \mathrm{mg}$ vs $60 \mathrm{mg}$, respectively). Similar to the European study, the median time to a $50 \%$ reduction in PSA was 14 days and the median time to $90 \%$ reduction was 56 days, in both treatment groups. After 12 months of treatment, the median PSA reduction from baseline was $96 \%$; overall, $7 \%$ of patients experienced PSA progression. ${ }^{37}$

\section{Safety and tolerability data from the phase II dose-finding studies}

In both studies, degarelix treatment was well tolerated, with most adverse events being mild to moderate in intensity and related to the known effects of androgen deprivation; there were no immediate-onset systemic allergic reactions Overall, $7 \%^{36}$ and $5 \%{ }^{37}$ of patients in these trials withdrew due to adverse events.

\section{Efficacy and safety conclusions} from the phase II dose-finding studies

Data from these trials suggested that degarelix $240 \mathrm{mg}$ appeared to be the optimal starter dose for evaluation in future studies, as this resulted in castrate testosterone levels in $>90 \%$ of patients within 3 days. ${ }^{36}$ In contrast, inadequate suppression occurred with the use of a $200 \mathrm{mg}$ starter dose used in the North American study. ${ }^{37}$ Two maintenance doses $(80 \mathrm{mg}$ and $160 \mathrm{mg}$ ) were also identified for future evaluation as no dose-dependent adverse events were noted in either study. In these studies, degarelix demonstrated effects on testosterone and PSA levels similar to those observed with orchiectomy.

\section{Phase III comparative study} Study design and patients

A 1-year, multicenter, randomized, open-label, parallel-group, phase III trial (CS21) was conducted, which was designed to demonstrate the statistical noninferiority of degarelix versus the $\mathrm{GnRH}$ receptor agonist leuprolide. ${ }^{38} \mathrm{In}$ this trial, patients with histologically confirmed prostate cancer (all stages), for whom ADT was indicated, were randomized to one of three treatment groups: degarelix (administered subcutaneously) at a starter dose of $240 \mathrm{mg}$ followed by monthly maintenance doses of either $80 \mathrm{mg}(240 / 80$ group; $\mathrm{n}=207)$ or $160 \mathrm{mg}$ (240/160 group; $n=202$ ), or monthly intramuscular injections of leuprolide depot $7.5 \mathrm{mg}(\mathrm{n}=201)$. In the leuprolide group, antiandrogens could also be given as flare protection at the investigator's discretion.

\section{Efficacy data}

\section{Primary analyses}

The primary analyses of data from the CS21 trial demonstrated that both degarelix doses were noninferior to leuprolide for the primary endpoint (testosterone response: serum testosterone $\leq 0.5 \mathrm{ng} / \mathrm{mL}$ at all monthly measurements between days 28 and 364; Table 1). ${ }^{38} \mathrm{~A}$ treatment response was achieved by $97.2 \%, 98.3 \%$ and $96.4 \%$ of patients in the degarelix 240/80 mg, 240/160 mg and leuprolide groups, respectively. Degarelix resulted in a more rapid treatment response than leuprolide and median testosterone levels were significantly lower in the degarelix groups by day $3(P<0.001$; Figure $4 a)$. At this time point, $>95 \%$ of patients in the degarelix groups had testosterone levels $\leq 0.5 \mathrm{ng} / \mathrm{mL}$. In contrast, no patients receiving leuprolide had castrate levels at day 3; indeed, 
patients in this group showed a median increase in testosterone of $65 \%$ compared with baseline levels at this time point and median levels were $>0.5 \mathrm{ng} / \mathrm{mL}$ until day 28 . Both degarelix doses were as effective as leuprolide at suppressing testosterone levels from day 28 to study end (Figure 4b). No patient receiving degarelix experienced testosterone surge ( $\geq 15 \%$ increase in testosterone level vs baseline during the first 2 weeks) or microsurges (testosterone increase $>0.25 \mathrm{ng} / \mathrm{mL}$ on days 255 or 259,3 or 7 days after the ninth injection). In contrast, 144 patients $(81 \%)$ in the leuprolide group experienced a testosterone surge, including 17 of the 23 patients (74\%) who received concomitant bicalutamide. Eight leuprolide patients (4\%) had microsurges, including four patients $(2 \%)$ whose testosterone increased $>0.5 \mathrm{ng} / \mathrm{mL}$ at the time points evaluated. Overall, patients in the leuprolide group showed a significant mean $0.05 \mathrm{ng} / \mathrm{mL}$ increase $(P<0.001)$ in testosterone levels on days $255 / 259$ compared with day 252 , whereas patients in the degarelix group showed a slight decrease.

In the degarelix groups, median LH and FSH levels decreased rapidly and remained suppressed until the end of the study, whereas LH and FSH levels showed an initial increase for patients in the leuprolide group, and FSH levels did not fall to the same extent as they did in the degarelix arms. In line with the testosterone results, PSA levels also declined more rapidly in the degarelix 240/80 and 240/160 mg arms, and at days $14(64 \%$ and $65 \%$ vs $18 \%)$ and $28(85 \%$ and $83 \%$ vs $68 \%$ ), significantly greater suppression was observed compared with leuprolide ( $P<0.001$; Figure 5a). Beyond day 28, PSA levels remained effectively suppressed in all treatment groups until the end of the 1-year study (Figure 5b). Overall, PSA failure (a PSA increase of $\geq 50 \%$ from nadir and $\geq 5 \mathrm{ng} / \mathrm{mL}$ on two consecutive occasions at least 2 weeks apart) occurred in $8.9 \%$ of patients in the degarelix $240 / 80 \mathrm{mg}$ group, $14.2 \%$ of those in the degarelix $240 / 160 \mathrm{mg}$ group, and $14.1 \%$ of those in the leuprolide $7.5 \mathrm{mg}$ group. ${ }^{38}$ In a subsequent analysis of PSA progression-free survival, a statistically lower $(P=0.0495$; log-rank test) risk of PSA failure or death was found for patients randomized to degarelix 240/80 mg compared with patients randomized to leuprolide (ITT population). ${ }^{39}$ Overall survival at 1 year did not differ significantly between degarelix 240/80 mg (probability of death by Day 364: 2.6\%; 95\% CI 1.1-6.2) and leuprolide groups $(4.9 \%$; 95\% CI 2.6-9.3).

\section{Post-hoc subgroup analyses}

Exploratory post-hoc subgroup analyses assessing the impact of baseline testosterone, disease stage and PSA level on activity were subsequently performed on data from the CS21 trial for the degarelix 240/80 mg group (the approved dose) versus the leuprolide group only. The effects of both treatments on total serum alkaline phosphatase (S-ALP) levels were also investigated. S-ALP is a recognized marker of metastatic bone disease in patients with prostate cancer. ${ }^{40}$ In both treatment arms, higher baseline testosterone led to slower achievement of castrate testosterone levels; however, achievement of castrate levels occurred significantly faster with degarelix than with leuprolide for all testosterone subgroups. ${ }^{41}$ Reduction in PSA levels was also significantly faster with degarelix than leuprolide in all testosterone subgroups $(P<0.0001)$. In the degarelix group, a rapid reduction in PSA began on day 1 , irrespective of baseline testosterone level. In contrast, there was a small increase in PSA on days 3 and 7 in the leuprolide group, which was somewhat larger in the subgroup of patients with baseline testosterone $\geq 5 \mathrm{ng} / \mathrm{mL}$ where the subsequent fall in PSA was also the slowest. In this subgroup of patients, the same level of PSA suppression was achieved for those receiving leuprolide and degarelix, but only after a delay of approximately 2 months in the leuprolide group. ${ }^{41}$

In additional analyses of the PSA data, it was found that PSA failures occurred mainly in patients with metastatic disease at baseline or PSA levels $>50 \mathrm{ng} / \mathrm{mL}$; no PSA failures occurred in those with baseline PSA $\leq 20 \mathrm{ng} / \mathrm{mL}$. ${ }^{39}$ Patients with metastatic disease or PSA levels $>20 \mathrm{ng} / \mathrm{mL}$ at baseline experienced numerically fewer PSA failures with degarelix compared with leuprolide. Patients with metastatic disease or those with PSA levels $>50 \mathrm{ng} / \mathrm{mL}$ at baseline also experienced greater reductions in S-ALP levels with degarelix than leuprolide. ${ }^{42}$ Patients in the degarelix group maintained S-ALP suppression throughout the 1-year study and did not display signs of therapy failure, as indicated by the late rises in S-ALP levels that were observed in patients receiving leuprolide.

\section{Safety and tolerability data}

In the CS21 trial, both degarelix and leuprolide were well tolerated, with most adverse events being mild or moderate in intensity. ${ }^{38}$ The most common adverse events observed during degarelix treatment were related to the known effects of androgen deprivation (hot flashes, weight increases) or the mode of administration (injection-site reactions; Table 2). There was a significantly higher incidence of injection-site reactions and chills with subcutaneous degarelix treatment than with the intramuscular leuprolide injection (40\% vs $<1 \%$; $P<0.001)$. Injection-site events occurred predominantly after the first dose, with their incidence declining 
A

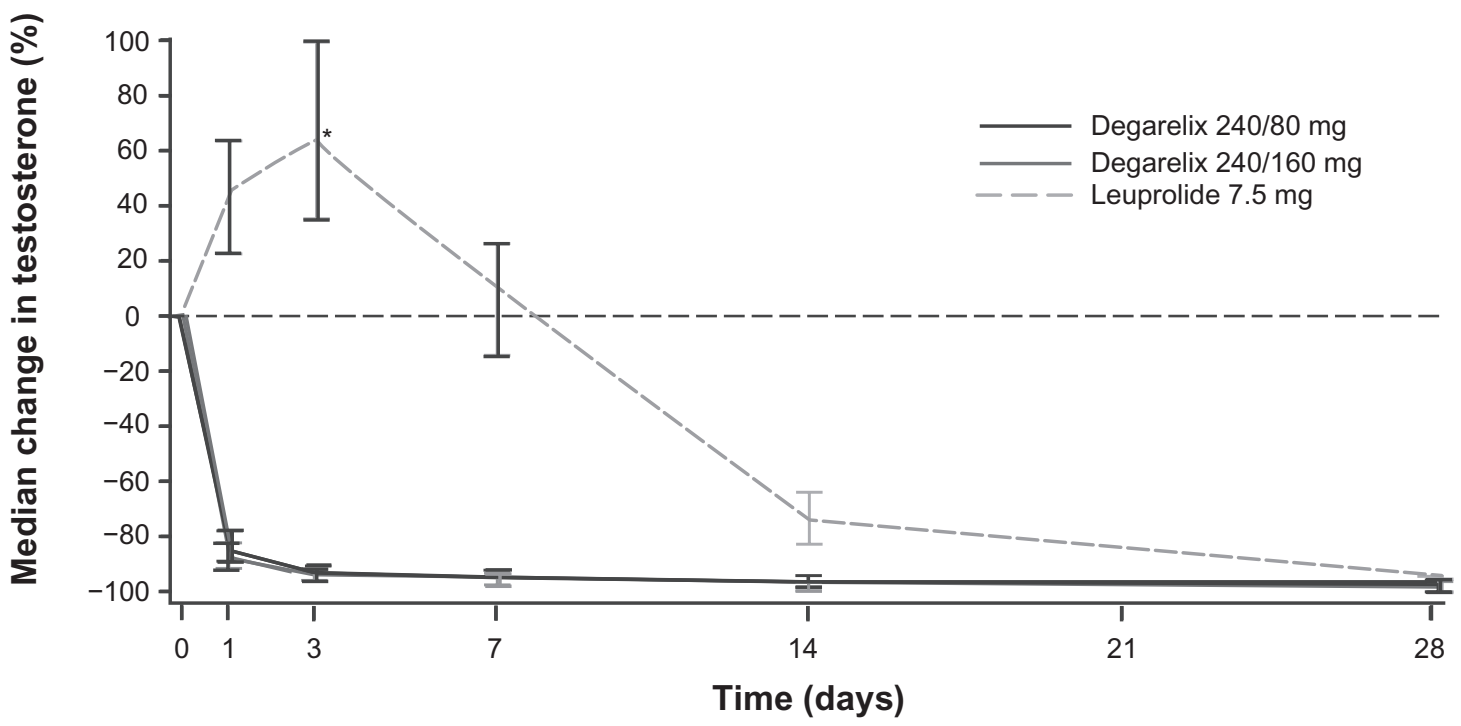

B

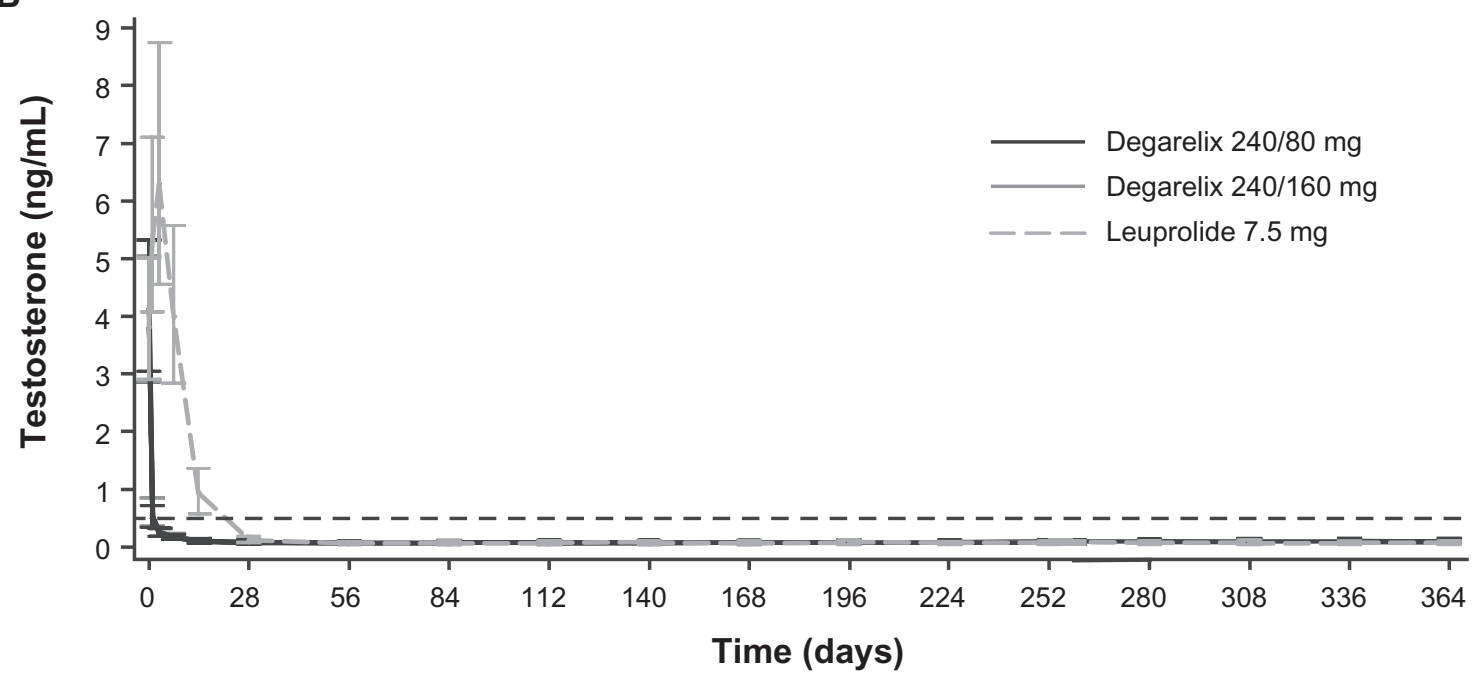

Figure 4 Median testosterone levels with degarelix and leuprolide. Panel A depicts the first month of treatment; Panel B shows data from across the I-year treatment period. ${ }^{38}$ Reproduced with permission from Klotz L, Boccon-Gibod L, Shore ND, et al. The efficacy and safety of degarelix: a I2-month, comparative, randomized, open-label, parallel-group phase III study in patients with prostate cancer. BJU Int. 2008; 102(I I): I53I-1538. ${ }^{38}$ Copyright (C) 2008 Blackwell Publishing Ltd. $* P<0.00$ I degarelix (both doses) versus leuprolide.

during maintenance treatment. Overall, 33\% of 409 starter dose injections and 4\% of 2244 and 2208 maintenance dose injections (240/80 and 240/160 mg groups, respectively) were associated with injection-site events. Only five patients ( $1 \%$ ) receiving degarelix discontinued treatment due to an injection-site reaction. Significantly more degarelix patients experienced chills (4\% vs $0 \% ; P<0.01)$, whereas the incidence of disease-related adverse events such as arthralgia (4\% vs 9\%; $P<0.05)$ and urinary tract infection (3\% vs 9\%; $P<0.01)$ were significantly higher with leuprolide. In an exploratory analysis of tolerability data, musculoskeletal and connective tissue disorders were found to be more common in patients receiving leuprolide than degarelix, irrespective of disease stage. ${ }^{43}$ Disease-related symptoms such as arthralgia and back pain occurred more frequently in leuprolide patients with metastatic disease than in degarelix patients with metastatic disease.

As observed in the phase II dose-finding studies, no immediate-onset systemic allergic reactions were reported during degarelix treatment. ${ }^{38}$ A similar proportion of patients in each group also experienced alanine aminotransferase/ aspartate aminotransferase changes, and there were no 
A

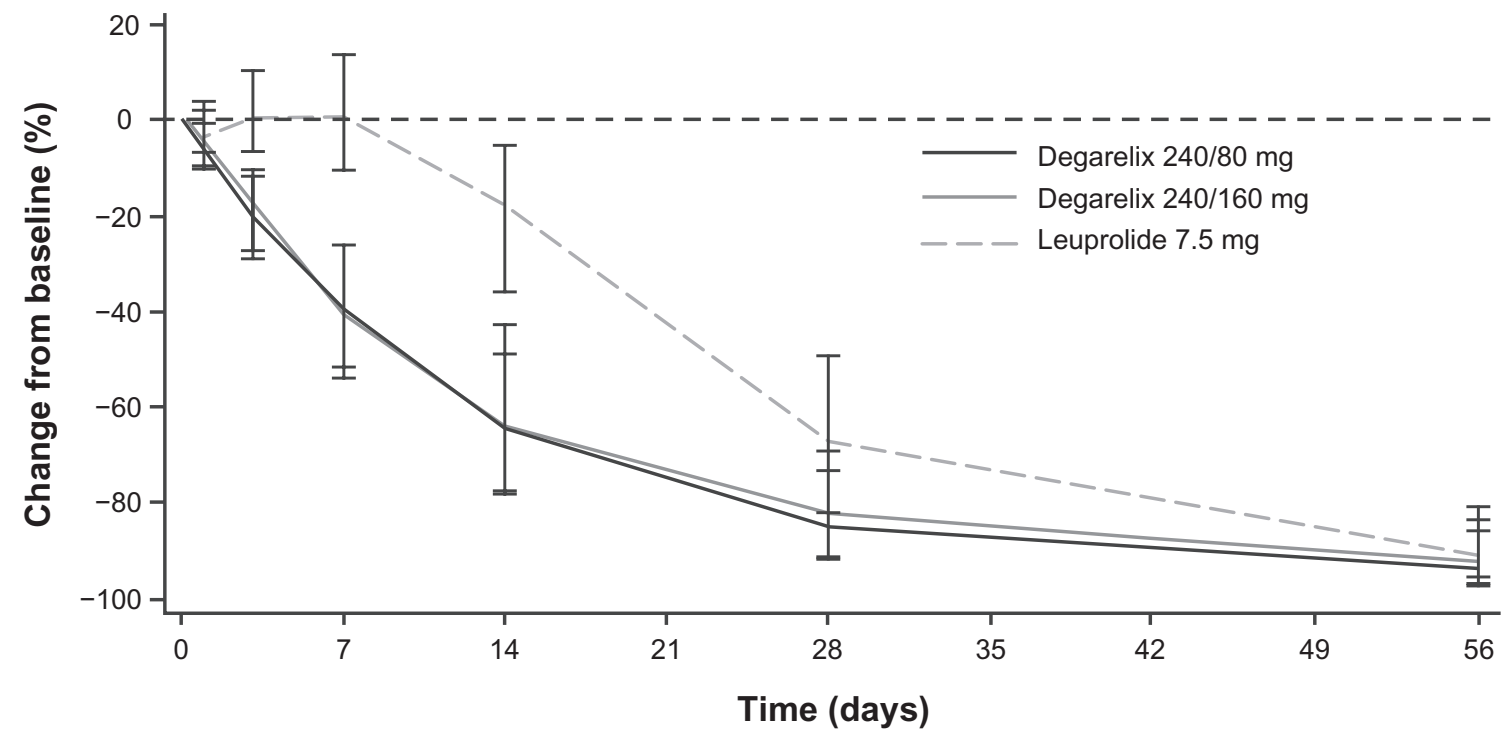

B

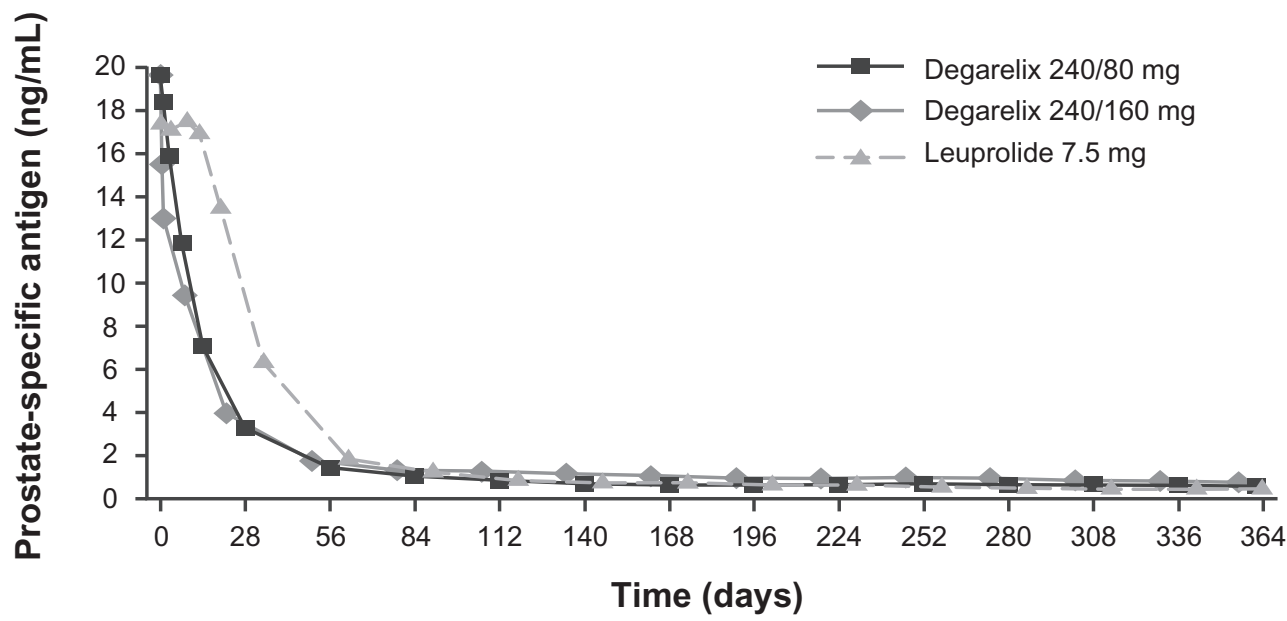

Figure 5 Median percentage change from baseline in PSA levels with degarelix and leuprolide. Panel A depicts the first month of treatment; Panel B shows data from across the I-year treatment period. Reproduced with permission from Klotz L, Boccon-Gibod L, Shore ND, et al. The efficacy and safety of degarelix: a I2-month, comparative, randomized, open-label, parallel-group phase III study in patients with prostate cancer. BJU Int. 2008; 102(I I): I53 I-I538. ${ }^{38}$ Copyright @ 2008 Blackwell Publishing Ltd.

statistically significant differences between groups in vital signs, body weight or QT interval.

Efficacy and safety conclusions from the phase III trial Data from this pivotal phase III trial demonstrated that degarelix was an effective and well-tolerated treatment for patients requiring ADT for prostate cancer. Both degarelix doses (240/80 and 240/160 mg) were as effective as leuprolide in terms of treatment response. Due to its immediate onset of action, FSH, LH, testosterone, and PSA levels fell more rapidly with degarelix than with leuprolide. Unlike the GnRH agonist leuprolide, degarelix did not induce a surge (or microsurges) in testosterone and therefore there is no requirement for concomitant antiandrogen flare protection. The safety profile of degarelix, although displaying hormonal side effects in line with ADT, differed from that of leuprolide, mainly with respect to disease-related events. The higher incidence of injection-site events with degarelix predominantly occurred after the first injection and may be due to the mode of administration and the injection volume. Based on the results of this trial, degarelix 240/80 mg was approved in December 2008 by the FDA for the treatment of patients in the USA with advanced prostate cancer. This was followed in February 2009 by EMEA approval of the same 
Table 2 Incidence and intensity of adverse events during degarelix and leuprolide treatment (incidence of $\geq 5 \%$ in any group)

\begin{tabular}{|c|c|c|c|c|}
\hline & Degarelix 240/80 mg & Degarelix 240//60 mg & Degarelix pooled & Leuprolide $7.5 \mathrm{mg}$ \\
\hline ITT analysis set, $\mathrm{n}$ & 207 & 202 & 409 & 201 \\
\hline Any adverse event, n (\%) & 163 (79) & $167(83)$ & $330(8 I)$ & $156(78)$ \\
\hline Injection-site reactions $\mathrm{s}^{\mathrm{a}}$ & $73(35)$ & $89(44)$ & $162(40)$ & $\mathrm{I}(<\mathrm{I})^{* * *}$ \\
\hline Hot flashes & $53(26)$ & $52(26)$ & $105(26)$ & $43(2 \mathrm{I})$ \\
\hline$A L T$ increase $^{b}$ & $20(10)$ & $17(8)$ & $37(9)$ & II (5) \\
\hline Weight increase & $18(9)$ & $22(11)$ & $40(10)$ & $24(12)$ \\
\hline Back pain & $12(6)$ & $12(6)$ & $24(6)$ & $17(8)$ \\
\hline Hypertension & $12(6)$ & $14(7)$ & $26(6)$ & $8(4)$ \\
\hline AST increase ${ }^{c}$ & $10(5)$ & II (5) & $21(5)$ & $6(3)$ \\
\hline Arthralgia & II (5) & $6(3)$ & $17(4)$ & $18(9)^{*}$ \\
\hline Urinary tract infection & $10(5)$ & $3(1)$ & $13(3)$ & $18(9)^{* *}$ \\
\hline Fatigue & $7(3)$ & $13(6)$ & $20(5)$ & $13(6)$ \\
\hline Hypercholesterolemia & $7(3)$ & $12(6)$ & $19(5)$ & $5(2)$ \\
\hline Chills & $7(3)$ & II (5) & $18(4)$ & $0 * *$ \\
\hline Constipation & $6(3)$ & II (5) & $17(4)$ & $10(5)$ \\
\hline \multicolumn{5}{|l|}{ Intensity, n (\%) } \\
\hline Mild & $138(67)$ & $145(72)$ & $283(69)$ & 138 (69) \\
\hline Moderate & II $3(55)$ & II $2(55)$ & $225(55)$ & IOI (50) \\
\hline Severe & $32(15)$ & $36(18)$ & $68(17)$ & $26(13)$ \\
\hline Life-threatening & $I(<I)$ & $2(<1)$ & $3(<1)$ & $5(2)$ \\
\hline Death $^{d}$ & $5(2)$ & $5(2)$ & $10(2)$ & $9(4)$ \\
\hline
\end{tabular}

alnjection-site reactions include injection-site pain, erythema, swelling, induration, and nodule.

'Overall, 28 (7\%) degarelix patients and $12(6 \%)$ leuprolide patients had ALT increases $>3 \times$ the upper limit of normal (ULN).

'Overall, 16 (4\%) of degarelix patients and 9 (4\%) leuprolide patients had AST increases $>3 \times$ the ULN.

${ }^{d}$ None of the deaths were considered related to treatment. Statistically significant differences between the pooled degarelix and leuprolide groups are indicated.

$* P<0.05$, ** $P<0.01$, *** $P<0.001$.

Reproduced with permission from Klotz L, Boccon-Gibod L, Shore ND, et al. The efficacy and safety of degarelix: a I2-month, comparative, randomized, open-label, parallelgroup phase III study in patients with prostate cancer. BJU Int. 2008;102(I I):I53 I-1538. ${ }^{38}$ Copyright @ 2008 Blackwell Publishing Ltd.

Abbreviations: ALT, alanine aminotransferase; AST, aspartate aminotransferase.

degarelix dose for the treatment of adult male patients with advanced hormone-dependent prostate cancer.

\section{Patient-focused perspectives}

Because of their mode of action, all hormonal therapies are associated with side effects that can affect physical, sexual and psychological functioning of men with prostate cancer and may have an adverse impact on a patient's quality of life. While it remains the "gold standard" ADT, orchiectomy is irreversible and associated with psychological drawbacks, and has therefore now largely been replaced by medical castration, as patients generally prefer this option. ${ }^{44} \mathrm{GnRH}$ agonists are currently the most commonly used form of medical ADT, as treatment with these agents is associated with improved quality of life compared with orchiectomy. ${ }^{44}$ Nonetheless, the clinical flare associated with GnRH agonists can worsen disease symptoms ${ }^{12}$ and deleteriously impact upon the quality of life of some patients with advanced disease. Co-administration of antiandrogens may reduce or eliminate flare, but is associated with an additional side effect burden and a higher cost.

Sexual dysfunction (eg, loss of libido and erectile dysfunction) is a common consequence of all types of prostate cancer therapy. ${ }^{45,46}$ Erectile dysfunction can be effectively treated in many men with the use of phosphodiesterase 5 inhibitors such as sildenafil or tadalafil. ${ }^{46}$ There is also much interest in the use of intermittent ADT regimens in prostate cancer, as this can reduce the incidence of sexual side effects during off-treatment phases, thereby improving quality of life. This type of treatment may be particularly suitable for younger patients with less aggressive disease. ${ }^{47}$ Many clinical trials are currently assessing the efficacy and safety of intermittent ADT, including several studies assessing the potential role of degarelix $240 / 80 \mathrm{mg}$ in such regimens.

Hot flashes are another common side effect of hormonal therapy, being experienced by most men undergoing ADT. ${ }^{46}$ These can be quite debilitating and may have a substantial impact on quality of life of some men. Transdermal estrogen ${ }^{48}$ 
or megestrol acetate ${ }^{49}$ can improve hot flashes, but are associated with gynecomastia and breast/nipple pain and sometimes also weight gain. Antidepressants such as paroxetine and venlafaxine have been shown to be effective in reducing hot flashes in women with breast cancer, and several small studies have suggested that these agents may also be beneficial in men with prostate cancer. ${ }^{50,51}$ As depression and emotional lability can also be a consequence of hormonal therapy, ${ }^{45}$ antidepressants may also have other positive effects on the patient. Gynecomastia and breast pain/tenderness occur commonly in men undergoing antiandrogen therapy and are also associated to a lesser extent with orchiectomy and GnRH agonist treatment. ${ }^{46}$ Prophylactic breast irradiation ${ }^{52}$ or tamoxifen treatment ${ }^{53}$ can be effective in reducing the incidence and severity of breast pain and gynecomastia, but are both associated with an additional side-effect burden.

ADT increases markers of bone turnover, and several reports have demonstrated that ADT with GnRH receptor agonists results in a progressive decrease in bone mineral density, with the risk of fracture and/or development of osteoporosis increasing with duration of treatment. ${ }^{46}$ Patients most at risk of adverse skeletal effects appear to be those with osteopenia at the start of treatment. ${ }^{45}$ Studies on the skeletal consequences of treatment with GnRH receptor blockers such as degarelix are currently lacking, although initial analyses of the effect of degarelix on S-ALP levels suggest improved suppression with this agent compared with leuprolide. ${ }^{42}$ Increased S-ALP levels can also reflect bone metastases progression $^{54}$ and therefore improved S-ALP suppression (as well as fewer PSA failure events) may be suggestive of better disease control with degarelix. Various agents are available for preventing bone loss in prostate cancer patients undergoing ADT, including bisphosphonates such as pamidronate and zoledronic acid. ${ }^{55,56}$ Lifestyle changes such as stopping smoking and increased resistance weight training in addition to calcium and vitamin D supplementation may also be helpful. ${ }^{45,46} \mathrm{GnRH}$ receptor agonist treatment also results in body composition changes that are accompanied by adverse metabolic consequences such as increased plasma cholesterol, triglycerides, glucose and insulin levels, which in turn increase risk of cardiovascular disease and diabetes. ${ }^{46}$

Regular patient follow-up may permit early diagnosis and treatment of any treatment-emergent side effects and may therefore also improve outcomes. The monthly injection schedule of degarelix is convenient and also enables the patient to receive regular contact and support from their healthcare provider. This has been shown to be especially important during the early stages of treatment and may also positively contribute to the patient's coping strategies and quality of life. ${ }^{57}$ Less regular contact may be preferable to patients later in their treatment course, when any emergent adverse events are already being effectively managed; studies assessing the efficacy and tolerability of a degarelix 3-monthly dosing schedule are currently ongoing.

As prostate cancer is more common in older men, patients often have and are being treated for comorbid conditions in addition to receiving ADT. As well as making it difficult to assess any quality-of-life changes specifically associated with ADT, this could potentially complicate their management. Therefore, the potential for any drug-drug interactions also needs to be examined before initiating therapy. Preclinical studies suggest that degarelix has a mild pharmacokinetic interaction profile and is therefore unlikely to be the subject or cause of clinically significant drug-drug interactions. ${ }^{29}$

\section{Summary and conclusions}

Orchiectomy is unacceptable to many prostate cancer patients, and so medical castration using GnRH receptor agonists now provides the mainstay of ADT for prostate cancer. The recently approved $\mathrm{GnRH}$ receptor blocker, degarelix, is as effective and well-tolerated as GnRH agonists but has the advantage of an immediate onset of action and faster testosterone and PSA suppression, without a surge or microsurges. The pharmacological effects of degarelix therefore more closely resemble those of orchiectomy. Although generally more acceptable to patients than orchiectomy, all forms of medical castration are associated with adverse events that may impact upon a patient's quality of life. However, with appropriate follow-up and treatment, many of these adverse events can be overcome. In summary, degarelix is an effective and well-tolerated agent that provides a useful addition to the hormonal armamentarium for prostate cancer, offering patients with hormone-sensitive advanced disease a valuable alternative treatment option.

\section{Acknowledgments and disclosures}

Reconstitution data for degarelix were provided by Pernille Rosted, Keith Fox and Jette Toft from Ferring Pharmaceuticals. Medical writing support was provided by Dawn Batty $\mathrm{PhD}$ of Bioscript Stirling Ltd and funded by Ferring Pharmaceuticals.

\section{References}

1. Huggins C, Stevens REJ, Hodges CV. Studies in prostatic cancer II. The effects of castration on advanced carcinoma of the prostate gland. Arch Surg. 1941;43:209-223.

2. FDA, US Food and Drug Administration: Cancer drug approval endpoints for prostate cancer 2009. Available from: http:/www.fda. gov/Drugs/DevelopmentApprovalProcess/DevelopmentResources/ CancerDrugs/ucm094586.htm; Accessed Nov 162009. 
3. Fleming MT, Morris MJ, Heller G, Scher HI. Post-therapy changes in PSA as an outcome measure in prostate cancer clinical trials. Nat Clin Pract Oncol. 2006;3(12):658-667.

4. Lilja H, Ulmert D, Vickers AJ. Prostate-specific antigen and prostate cancer: prediction, detection and monitoring. Nat Rev Cancer. 2008;8(4):268-278.

5. Huhtaniemi I, White R, McArdle CA, Persson BE. Will GnRH antagonists improve prostate cancer treatment? Trends Endocrinol Metab. 2009;20(1):43-50.

6. Rohl HF, Beuke HP. Effect of orchidectomy on serum concentrations of testosterone and dihydrotestosterone in patients with prostatic cancer. Scand J Urol Nephrol. 1992;26(1):11-14.

7. Heidenreich A, Bolla M, Joniau S, et al. Guidelines on Prostate Cancer. European Association of Urology, 2009. Available from: http://www.uroweb. org/professional-resources/guidelines/online; Accessed Oct 262009.

8. Conn PM, Crowley WF Jr. Gonadotropin-releasing hormone and its analogues. N Engl J Med. 1991;324(2):93-103.

9. Sasagawa I, Kubota Y, Nakada T, et al. Influence of luteinizing hormonereleasing hormone analogues on serum levels of prostatic acid phosphatase and prostatic specific antigen in patients with metastatic carcinoma of the prostate. Int Urol Nephrol. 1998;30(6):745-753.

10. Tomera K, Gleason D, Gittelman M, et al. The gonadotropin-releasing hormone antagonist abarelix depot versus luteinizing hormone releasing hormone agonists leuprolide or goserelin: initial results of endocrinological and biochemical efficacies in patients with prostate cancer. J Urol. 2001;165(5):1585-1589.

11. Thompson IM, Zeidman EJ, Rodriguez FR. Sudden death due to disease flare with luteinizing hormone-releasing hormone agonist therapy for carcinoma of the prostate. J Urol. 1990;144(6):1479-1480.

12. Van Poppel H, Nilsson S. Testosterone surge: rationale for gonadotropinreleasing hormone blockers? Urology. 2008;71(6):1001-1006.

13. Perlmutter MA, Lepor H. Androgen deprivation therapy in the treatment of advanced prostate cancer. Rev Urol. 2007;9 Suppl 1:S3-S8.

14. Kaisary AV, Iversen P, Tyrrell CJ, Carroll K, Morris T. Is there a role for antiandrogen monotherapy in patients with metastatic prostate cancer? Prostate Cancer Prostatic Dis. 2001;4(4):196-203.

15. Heidenreich H, Aus G, Abbou CC, et al. Guidelines on prostate cancer. European Association of Urology, 2007. Available from: http://www. uroweb.org/fileadmin/user_upload/Guidelines/07_Prostate_Cancer_ 2007.pdf; Accessed Aug 102009.

16. Sharifi R, Browneller R. Serum testosterone suppression and potential for agonistic stimulation during chronic treatment with monthly and 3-month depot formulations of leuprolide acetate for advanced prostate cancer. J Urol. 2002;168(3):1001-1004.

17. Zinner NR, Bidair M, Centeno A, Tomera K. Similar frequency of testosterone surge after repeat injections of goserelin (Zoladex) $3.6 \mathrm{mg}$ and $10.8 \mathrm{mg}$ : results of a randomized open-label trial. Urology. 2004;64(6):1177-1181

18. Morote J, Orsola A, Planas J, et al. Redefining clinically significant castration levels in patients with prostate cancer receiving continuous androgen deprivation therapy. J Urol. 2007;178(4 Pt 1):1290-1295.

19. Perachino M, Cavalli V, Bravi F. Testosterone levels in patients with metastatic prostate cancer treated with luteinizing hormone-releasing hormone therapy: prognostic significance? BJU Int. 2009. Aug 28 [Epub ahead of print]

20. Jockenhovel F, Bhasin S, Steiner BS, Rivier JE, Vale WW, Swerdloff RS Hormonal effects of single gonadotropin-releasing hormone antagonist doses in men. J Clin Endocrinol Metab. 1988;66(5):1065-1070.

21. Salameh W, Bhasin S, Steiner B, McAdams LA, Peterson M, Swerdloff R. Marked suppression of gonadotropins and testosterone by an antagonist analog of gonadotropin-releasing hormone in men. Fertil Steril. 1991;55(1):156-164.

22. Bagatell CJ, Conn PM, Bremner WJ. Single-dose administration of the gonadotropin-releasing hormone antagonist, Nal-Lys (antide) to healthy men. Fertil Steril. 1993;60(4):680-685.

23. Bagatell CJ, Rivier JE, Bremner WJ. Dose effects of the gonadotropinreleasing hormone antagonist, Nal-Glu, combined with testosterone enanthate on gonadotropin levels in normal men. Fertil Steril. 1995; 64(1):139-145.
24. Klingmuller D, Schepke M, Enzweiler C, Bidlingmaier F. Hormonal responses to the new potent GnRH antagonist Cetrorelix. Acta Endocrinol (Copenh). 1993;128(1):15-18.

25. Broqua P, Riviere PJ, Conn PM, Rivier JE, Aubert ML, Junien JL. Pharmacological profile of a new, potent, and long-acting gonadotropinreleasing hormone antagonist: degarelix. J Pharmacol Exp Ther. 2002; 301(1):95-102.

26. Debruyne F, Bhat G, Garnick MB. Abarelix for injectable suspension: first-in-class gonadotropin-releasing hormone antagonist for prostate cancer. Future Oncol. 2006;2(6):677-696.

27. PR Newswire. FDA approves Ferring Pharmaceuticals' Degarelix (generic name) for the treatment of advanced prostate cancer. PR Newswire, Europe Ltd, 2008. Available from: http://www.prnewswire. co.uk/cgi/news/release?id=245656; Accessed Mar 22009.

28. Jiang G, Stalewski J, Galyean R, et al. GnRH antagonists: a new generation of long acting analogues incorporating p-ureido-phenylalanines at positions 5 and 6. J Med Chem. 2001;44(3):453-467.

29. European Medicines Agency. Assessment report for Firmagon (Doc. Ref: EMEA/CHMP/635761/2008). Available from: http://www.emea. europa.eu/humandocs/PDFs/EPAR/firmagon/H-986-en6.pdf; Accessed Apr 282009.

30. Koechling W. Effect of various GnRH antagonists on histamine release from human skin. Poster presented at the 8th International Symposium on GnRH Analogues in Cancer and Human Reproduction; 2005 Nov 2; Salzburg, Austria.

31. Agerso H, Koechling W, Knutsson M, Hjortkjaer R, Karlsson MO. The dosing solution influence on the pharmacokinetics of degarelix, a new GnRH antagonist, after s.c. administration to beagle dogs. Eur J Pharm Sci. 2003;20(3):335-340.

32. Doehn C, Sommerauer M, Jocham D. Drug evaluation: Degarelix a potential new therapy for prostate cancer. IDrugs. 2006;9(8):565-572.

33. Degarelix US prescribing information. 2008. Available from: http://www. fda.gov/cder/foi/label/2008/022201lbl.pdf; Accessed Apr 282009.

34. Balchen T, Agerso H, Olesen TK, Jensen JK, Senderovitz T. Pharmacokinetics, pharmacodynamics, and safety of a novel fast-acting gonadotropinreleasing hormone receptor blocker, degarelix, in healthy men. Poster presented at the 8th International Symposium on GnRH Analogues in Cancer and Human Reproduction; 2005 Nov 2; Salzburg, Austria.

35. Iversen $P$, Van Poppel H, Tammela T, et al. Determining the optimal initiation and maintenance dose of degarelix for hormone therapy of prostate cancer patients. Poster presented at the 28th Congress of the Société Internationale d'Urologie; 2006 Nov 12-15; Cape Town, South Africa.

36. Van Poppel H, Tombal B, de la Rosette JJ, Persson BE, Jensen JK, Kold OT. Degarelix: a novel gonadotropin-releasing hormone (GnRH) receptor blocker - results from a 1-yr, multicentre, randomised, phase II dosage-finding study in the treatment of prostate cancer. Eur Urol. 2008;54(4):805-813.

37. Gittelman M, Pommerville PJ, Persson BE, Jensen JK, Olesen TK. A 1-year, open label, randomized phase II dose finding study of degarelix for the treatment of prostate cancer in North America. J Urol. 2008;180(5):1986-1992.

38. Klotz L, Boccon-Gibod L, Shore ND, et al. The efficacy and safety of degarelix: a 12-month, comparative, randomized, open-label, parallelgroup phase III study in patients with prostate cancer. BJU Int. 2008; 102(11):1531-1538.

39. Tombal B, Miller K, Boccon-Gibod L, et al. Additional analysis of the secondary endpoint of biochemical recurrence rate in a phase 3 trial (CS21) comparing degarelix $80 \mathrm{mg}$ versus leuprolide in patients with prostate cancer segmented by baseline characteristics. Eur Urol. 2009. Nov 20 [Epub ahead of print].

40. Jung K, Lein M, Stephan C, et al. Comparison of 10 serum bone turnover markers in prostate carcinoma patients with bone metastatic spread: diagnostic and prognostic implications. Int J Cancer. 2004;111(5):783-791.

41. Damber JE, Tammela T, Abrahamsson PA, et al. Comparing testosterone and PSA for different baseline testosterone concentrations during initiation of degarelix and leuprolide treatment [abstract]. Eur Urol. 2009;Suppl 8:130. 
42. Schröder FH, Tombal B, Miller K, et al. Changes in alkaline phosphatase levels in patients with prostate cancer receiving degarelix or leuprolide: results from a 12-month, comparative, phase III study. BJU Int. 2009. Nov 13 [Epub ahead of print].

43. Iversen P, Jensen JK, Olesen TK, Persson BE. Phase III trial of degarelix vs leuprolide: comparing safety and tolerability. Presented at the World Congress on Controversies in Urology; 2009 Feb 5; Lisbon, Portugal. Abstract 618148.

44. Cassileth BR, Soloway MS, Vogelzang NJ, et al. Quality of life and psychosocial status in stage D prostate cancer. Zoladex Prostate Cancer Study Group. Qual Life Res. 1992;1(5):323-329.

45. Gomella LG. Contemporary use of hormonal therapy in prostate cancer: managing complications and addressing quality-of-life issues. BJU Int. 2007;99 Suppl 1:25-29.

46. Michaelson MD, Cotter SE, Gargollo PC, Zietman AL, Dahl DM, Smith MR. Management of complications of prostate cancer treatment. CA Cancer J Clin. 2008;58(4):196-213.

47. Gleave M, Klotz L, Taneja SS. The continued debate: intermittent vs continuous hormonal ablation for metastatic prostate cancer. Urol Oncol. 2009;27(1):81-86.

48. Gerber GS, Zagaja GP, Ray PS, Rukstalis DB. Transdermal estrogen in the treatment of hot flushes in men with prostate cancer. Urology. 2000;55(1):97-101.

49. Loprinzi CL, Michalak JC, Quella SK, et al. Megestrol acetate for the prevention of hot flashes. N Engl J Med. 1994;331(6):347-352.

50. Loprinzi CL, Pisansky TM, Fonseca R, et al. Pilot evaluation of venlafaxine hydrochloride for the therapy of hot flashes in cancer survivors. J Clin Oncol. 1998;16(7):2377-2381.
51. Loprinzi CL, Barton DL, Carpenter LA, et al. Pilot evaluation of paroxetine for treating hot flashes in men. Mayo Clin Proc. 2004;79(10): 1247-1251.

52. Widmark A, Fossa SD, Lundmo P, et al. Does prophylactic breast irradiation prevent antiandrogen-induced gynecomastia? Evaluation of 253 patients in the randomized Scandinavian trial SPCG-7/SFUO-3. Urology. 2003;61(1):145-151.

53. Saltzstein D, Sieber P, Morris T, Gallo J. Prevention and management of bicalutamide-induced gynecomastia and breast pain: randomized endocrinologic and clinical studies with tamoxifen and anastrozole. Prostate Cancer Prostatic Dis. 2005;8(1):75-83.

54. Lein M, Wirth M, Miller K, et al. Serial markers of bone turnover in men with metastatic prostate cancer treated with zoledronic acid for detection of bone metastases progression. Eur Urol. 2007;52(5): 1381-1387.

55. Smith MR, McGovern FJ, Zietman AL, et al. Pamidronate to prevent bone loss during androgen-deprivation therapy for prostate cancer. N Engl J Med. 2001;345(13):948-955.

56. Ryan CW, Huo D, Bylow K, et al. Suppression of bone density loss and bone turnover in patients with hormone-sensitive prostate cancer and receiving zoledronic acid. BJU Int. 2007;100(1):70-75.

57. Lebret T, Bouregba A. Roles of the urologist and nurse from the perspective of patients with prostate cancer receiving luteinizing hormone-releasing hormone analogue therapy. BJU Int. 2008;102(10): 1419-1424.

58. Anderson J. Degarelix: a novel gonadotropin-releasing hormone blocker for the treatment of prostate cancer. Future Oncol. 2009;5(4): 433-443.
Cancer Management and Research

\section{Publish your work in this journal}

Cancer Management and Research is an international, peer-reviewed open access journal focusing on cancer research and the optimal use of preventative and integrated treatment interventions to achieve improved outcomes, enhanced survival and quality of life for the cancer patient. The journal welcomes original research, clinical \& epidemiological

\section{Dovepress}

studies, reviews \& evaluations, guidelines, expert opinion \& commentary, case reports \& extended reports. The manuscript management system is completely online and includes a very quick and fair peerreview system, which is all easy to use. Visit http://www.dovepress.com/ testimonials.php to read real quotes from published authors. 